\title{
LATVIJOS IR LENKIJOS KARINĖS ŽVALGYBOS BENDRADARBIAVIMO 1919-1939 METAIS ESKIZAS
}

\author{
Dr. Ēriks Jēkabsons \\ Latvijos universitetas
}

Lenkijos vyriausybė ir pas J. Pilsudskis santykiams su naujai suskūrusia Latvija 1919 m. vasarą teikè nemažą reikšmę. Tai liudija faktas, kad į Latviją buvo nusiųstas kapitonas Aleksandras Myškovskis (Myszkowski), kuris iki tol ejo Lenkijos kariuomenès (LK) Generalinio štabo II skyriaus sekcijos „Wschod“(,Rytai“) vadovo pareigas (kaip karinis atstovas, o nuo 1919 m. gruodžio - kaip pirmasis Lenkijos karinis ataše Latvijoje). Akivaizdu, kad eidamas tas pareigas jis, kaip ir anksčiau, buvo susijęs su minètu skyriumi. Jis pats gruodžio pabaigoje LK Vadovybės vardu pasirašé su latviais slaptą sutartị dèl bendros veiklos išvaduojant Latgalą nuo bolševikų. Bendra akcija prasidejjo $1920 \mathrm{~m}$. sausio 3 d. ir iki vasario pradžios visa Latvijos teritorija buvo išlaisvinta. Balandžio ménesị sudaryta nauja Latvijos ir Lenkijos sutartis, pagal kurią atskiri lenkų daliniai liko tiktai Daugpilyje (Dyneburge). Tie daliniai liepos mėnesî, Raudonosios Armijos atakos metu, buvo atitraukti į Lenkiją. Per visą karinio bendradarbiavimo laikotarpị fronte A. Myškovskis palaikè glaudžius ryšius su Latvijos kariuomenès Vyriausiojo vado štabu, taip pat keitèsi žvalgybos informacija apie Sovietų Rusiją ir Lietuvą ${ }^{1}$.

${ }^{1}$ Centralne Archiwum Wojskove (toliau - CAW), Akta personalne (A. Myszkowski), 1969/89/3610; Latvijas Valsts vēstures archīvs (toliau-LVVA), f. 1474, ap. 2, b. 3, 1. 1; Jēkabsons Ē. Pulkownik Aleksander Myszkowski a Lotwa // Polak na Lotwie.- 1999, Nr. 1, p. 5-7. 
Tam tikras bendradarbiavimas vyko ir tarp padalinių, dalyvavusiu 1920 m. žiemos karinejje akcijoje. Latvijai atstovavo papulkininkis (pulkininkas leitenantas) A. Veisas (Veiss), veikiantis E. Rydzo-Smiglo štabo grupejje.

1920 m. pavasarị bei vasarą Latvijos kariuomenès Vyriausiojo vado štabas reguliariai tęsė politinio ir karinio pobūdžio informacijos teikimą A. Myškovskiui Rygoje (apie Raudonosios Armijos judejjimą, sovietų slaptosios policijos agentus ir t. t.). Jis netgi gavo tiesioginę informaciją iš Latvijos ir Sovietų Rusijos taikos derybų Maskvoje dalyvio štabo papulkininkio K. Ramačio - apie jų eigą (gegužès mėnesi jis grịžo iš Maskvos ị Rygą), taip pat reguliariai aptardavo tų derybų eigą su vyriausiuoju vadu J. Balodžiu ir jo štabo vadu P. Radziniu ${ }^{2}$. Be to, minètasis K. Ramatis pateikè A. Myškovskiui svarbių duomenų apie turinčius įvykti Raudonosios Armijos pergrupavimus, o A. Myškovskis šią informaciją nedelsdamas perdave ị Varšuvą ${ }^{3}$.

Dẻl îvykių Lenkijos ir Sovietų Rusijos fronte planuota Baltijos valstybių konferencija prasidejjo Bulduriuose prie Rygos tiktai 1920 m. rugpjūtị, jau po Latvijos ir Sovietų Rusijos taikos sudarymo (rugpjūčio 11 d.). Konferencijoje, neatsižvelgiant ị nenumatytą kliūtị - Lenkijos ir Lietuvos konfliktą, buvo priimtas karinio ir politinio bendradarbiavimo konvencijos projektas (deja, ne viena iš šalių dèl tarpusavio nesutarimų priimtų konvencijų per nustatytą terminą neratifikavo ir jos neịsi-

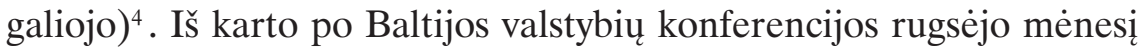
Rygoje prasidejo Lenkijos ir Sovietų Rusijos taikos derybos.

Latvijos ir Lenkijos santykiai tuo laikotarpiu palyginti buvo labai geri. A. My kovskis, pagal Var uvos įsakymą 1920 m. vasarą Rygoje ypač suaktyvino žvalgybos veiklą prieš Sovietų Rusiją (per jo paties organizuotą agentų tinklą „Dor" pavyko informuoti Varšuvą apie planuo-

${ }^{2}$ LVVA, f. 3601, ap. 366, b. 21, 1. 21.; f. 6033, ap. 1, b. 24, 1. 40; Archiwum Akt Nowych (toliau: AAN), Attachaty, A-II, 64/1, k. 379, 446.

3Peplonski A. Wywiad w wojnie polsko-bolszewickiej 1919-1920. - Warszawa, 1999, p. 66.

${ }^{4}$ Počs K. Sanitārā kordoną valgos. - Rìga, 1971, p. 108. 
jamas Raudonosios Armijos atakų kryptis rugpjūčio pradžioje) $)^{5}$. Rugsèjo 29 d. jis pranešè, kad „dèl puikiausių santykių“ jam pavyko gauti Latvijos kariuomenès Vyriausiojo vado štabo Užsienio žvalgybos skyriaus sutikimą pasiųsti ị Maskvą Lenkijos agentą, kaip Latvijos diplomatinès atstovybės darbuotoją, su Latvijos diplomatiniu pasu. Tas agentas Maskvoje užmegztų ryši su ten dirbančiais kitais Lenkijos žvalgybos agentais ir net gautų savo dispozicijon „specialią žvalgybos grupę“, kuriai slaptai vadovautų. Latviai sutiko, kad gauta informacija būtų siunčiama kaip diplomatinis paštas ị Latviją, ir todèl Latvijos pusè išreiškè sutikimą padidinti kurjerių skaičių su sąlyga, kad Lenkijos pusẻ pati mokès „savo" kurjeriui atlyginimą ${ }^{6}$. Nepavyko rasti to konkretaus plano iggvendinimo patvirtinimo, tačiau panašu, kad jis nepavyko. Abiejų šalių žvalgybų bendradarbiavimas buvo tęsiamas it toliau: dar $1921 \mathrm{~m}$. sausio 26 d. A. Myškovskis praneše iš Rygos, kad Latvijos žvalgybininkų išsiuntimas ị Rusiją be susitarimo su Latvijos žvalgyba - „sunkus, iš principo galimas, kad ir per konsorciumą, sudarytą prekybai su sovietais, su kuriais turiu ryšių“. Tinkamiausiu dalyku buvo laikomas žvalgybininkų permetimo taisyklių nustatymas su Latvijos štabo Užsienio žvalgybos sektoriumi ${ }^{7}$.

Lenkijos ir Sovietų Rusijos taikos derybos Rygoje tęsèsi iki 1921 m. kovo - minètu gerų Latvijos ir Lenkijos santykių laikotarpiu. Tai lëmè ir gana didelę paramą, kurią teikẻ Latvijos štabas: Lenkijos pusei buvo reguliariai pateikiamos telegramų tekstų, kurias sovietų delegacija siunte ị Maskvą Latvijos telegrafu, kopijos ${ }^{8}$. A. Peplonskis taip pat pažymėjo, kad ịstaiga, kuriai vadovavo vienas iš Lenkijos karinių ekspertų, esantis delegacijos sudettyje, gaudavo informacijos, turinčios kontržvalgybinę reikšmę, daugiausia iš Latvijos kariuomenès štabo ${ }^{9}$.

Pagal Baltijos valstybių konferencijos nutarimą jau spalio 18-30 d. Rygoje susitiko Latvijos, Lenkijos, Estijos, Suomijos ir Ukrainos štabų

\footnotetext{
${ }^{5}$ Peplonski A. Wywiad polski na ZSRR 1921-1939. - Warszawa, 1996, p. 26.

${ }^{6}$ AAN, Attachaty, A-II, 165/1, k. 144-145.

${ }^{7}$ Peplonski A. Wywiad polski na ZSRR. - p. 138.

${ }^{8}$ LVVA, f. 2575 , ap. 15 , b. $2,1.35$.

${ }^{9}$ Peplonski A. Wywiad polski na ZSRR. - P. 147.
} 
atstovai. Oficialus tikslas buvo išsamiai parengti būsimos konvencijos projektą ${ }^{10}$. Projekte buvo numatyta bendras visų valstybių veikimas tuo atveju, jeigu vieną iš jų užpultų Sovietų Rusija. Baigiantis tiems pasitarimams ị Rygą atvyko Lenkijos Generalinio štabo II skyriaus viršininkas pulkininkas I. Matuševskis (Matuszewski), kad suderintų su Baltijos valstybių štabais žvalgybos veiklą prieš Sovietų Rusiją ir atliktų žvalgybos tinklo prieš Rusiją ir Lietuvą inspekciją (šis tinklas Latvijoje kuriamas paaukštinto ị majorus A. Myškovskio). I. Matuševskis turejjo keletą svarbiu pokalbių su Latvijos kariuomenès vadovybe ${ }^{11}$.

Žinoma, kad nepaisant nurodytų sąlygų, neprisidejjusių prie Baltijos valstybių suartejimo, nebuvo ratifikuota ir karinè konvencija. Dèl to tolesniam kariniam Latvijos ir Lenkijos bendradarbiavimui visą tarpukario laikotarpị i̇taką daré palyginti komplikuoti santykiai arba apskritai pagerejję politiniai abiejų šalių santykiai. Svarbus tuose santykiuose buvo ir žvalgybų bendradarbiavimas. Visų pirma jis vyko per abiejų valstybių karinius atašè. Lenkijos atašè Rygoje, be to, dar vadovavo Lenkijos žvalgybos tinklui Latvijoje, nukreiptam prieš SSSR ir Lietuvą. Iki 1921 m. tas pareigas ejjo majoras A. Myškovskis, 19211926 m. (iki J. Pilsudskio perversmo gegužès mėn., kai buvo pašalintas iš pareigų kaip J. Pilsudskio priešininkas) ${ }^{12}$ - komandorasleitenantas B. Jarocinskis, 1926-1931 m. - majoras (vèliau - papulkininkis) S. Kara, 1931-1936 m. - majoras A. Liebechas, 1936-1939 m. - majoras F. Bžeskvinskis (Brzeskwinski). Rygoje taip pat nuolatos dirbo atašé padejejejas, kuris tiesiogiai vadovavo žvalgybos darbui. Tas pareigas èjo (net ir kaip žvalgybos ịstaigos vadovas) leitenantas A. Klotzas (1921 m.), leitenantas E. Kanievskis (E. Kaniewski) (19211922 m.), véliau - leitenantas J. Lemanskis, kapitonas (nuo 1928 metų - majoras) F. Tomčukas (Tomczuk), kapitonas S. Paprockis, kapitonas Radomskis (1929-1936 m.) ${ }^{13}$. Žvalgybos ịstaiga Latvijoje turèjo kriptonimą „Gorin“, nuo 1922 m. - „0-5“, vèliau - „Wiera“, nuo

\footnotetext{
${ }^{10}$ Spsiedzi wobec wojny 1920 roku. - Londyn, 1990. - P. 245-247.

${ }^{11}$ Skrzypek A. Zwiazek Baltycki. -Warszawa, 1972, p. 70-72.

${ }^{12}$ LVVA, f. 3235, ap. 1/22, b. 462, 1. 24.

${ }^{13}$ Latvijas Kareivis. - 19280928 Dzwon. -192911 27.
} 
trečiojo dešimtmečio vidurio - „Nord“( „P-1“), 1934-1938 m. - „Rok“ (pagal konsulato sekretoriaus K. Rokickio pavardę), 1938-1939 m. „Lotysz“ („Latvis“) ${ }^{14}$.

Lenkijos žvalgybos tinklo Latvijoje struktūra trečiojo dešimtmečio pradžioje (1921 m. gegužès mèn.) atrode taip: 1921 metais gegužę įkurta įstaiga „Rok“, kurios viršininkas buvo A. Klotzas, stebejo postų „Moskwa“ („Maskva“), „Kowno“ („Kaunas“), „Dyneburg“ („Daugpilis") veiklą. Pagalbą stebint sovietų pasiuntinybę Rygoje A. Klotzui teike ir Latvijos politinès policijos viršininkas V. Alpis. İdomu tai, kad A. Klotzui pavyko užverbuoti vieną iš Latvijos žvalgybos karininkų (,konfidentą"), kuris dirbo už pinigus giliai užsikonspiravęs, tačiau neteikdavo ypač svarbios informacijos. Pagal instrukciją $1921 \mathrm{~m}$. rugpjūčio $10 \mathrm{~d}$. Lenkijos Generalinio štabo atašè biuras Rygoje buvo atsakingas už žvalgybą Peterburgo karinejje apygardoje ir Vakarų karinejje apygardoje (Velikije Luki, Riazanè, Smolenskas, Vitebskas), už informaciją apie tranzitą per Latviją i Rusiją ir centrines kariuomenès institucijas Maskvoje). $1921 \mathrm{~m}$. liepą Rygos ataše biurui priklausantis postas Maskvoje (vadovas - seržantas V. Teresiakas) gavo informaciją iš Raudonosios Armijos Vyriausiojo štabo geležinkelių skyriaus ir stengèsi užmegzti kontaktą su Operaciniu skyriumi, ryšys su Ryga buvo palaikomas per Latvijos štabo žvalgybos pasiuntinius, postas Kaune (vadovas - F. Jagielskis) - iš Lietuvos kariuomenés žvalgybos struktūrų ir iš 2-os kariuomenès karininkų, ryšys su Ryga - per Mitaują (Jelgavą), postas Daugpilyje (vadovas - Formakovas (Formakow) vykdè asmenų, atvykstančių iš Sovietų Rusijos ir vykstančiu i i Lenkiją, gynybinę kontrolę ir puolamają karinę-politinę žvalgybą Pskovo-Vitebsko-Polocko rajone. To posto veikla buvo sunkesnè dèl priešiškos Latvijos žvalgybos struktūrų veiklos (ji prasidejo dèl įtarimų, kad Lenkija turi ketinimų, susijusių su teritorine Daugpilio ir Ilukstès apskrities 6 valsčiu priklausomybe, - tai buvo abiejų valstybių teritorinio ginčo objektas). Postas „Koszkin“ Rygoje (buvęs karininkas Smirnovas) turejo slaptą žvalgą Sovietų Rusijos pasiuntinybeje (prekybos delegacijos narị), tos pasiuntinybės Spaudos

${ }^{14}$ Peplonski A. Wywiad polski na ZSRR. - P. 147-148. 
biure, palaikė ryši su Latvijos muitininku Petrosevu, Lietuvos kariuomenès karininku Šiauliuose. Postas „Jurgen“ Rygoje (pavèliavininkas B. Kankovskis) turèjo ryšių su Latvijos ir Vokietijos žvalgyba, gynybinès žvalgybos postas „Manfred“ Rygoje (vadovas - konsulato pasų ir vizų sektoriaus seržantas F. Machajevskis) kontroliavo atvykstančius iš Rusijos i Lenkiją, turejo ryšių su Latvijos telegrafo ir radiotelegrafo darbuotojais, kurie pateikdavo telegramų, išsiųstų i Sovietų Rusijos pasiuntinybę, kopijas. Atašè padejjëjas A. Klotzas palaikè ryšį ne tik su Latvijos žvalgyba, bet ir su Prancūzijos, Anglijos misija ir Estijos atašė biuru Rygoje. Informacija apie Lietuvą oficialiai ateidavo iš Latvijos užsienio žvalgybos karininko A. Rušmanio, atsakingo už šios krypties darbą, ir dar iš vieno tos žvalgybos karininko (neoficialiai) Berzinio, taip pat - iš Latvijos politinès policijos agento Trapeznikovo. Jau nuo 1921 m. sausio (ar dar anksčiau) atašè biuras iš Latvijos štabo kas mènesi gaudavo Latvijos žvalgybos darbo rezultatus, susijusius su sovietinès kariuomenès dislokacija prie sienos. $1921 \mathrm{~m}$. rugpjūčio 11 d. „Jurgen“ - pavèliavininkis Jankovskis buvo perkeltas ị Daugpilị kaip etapinio punkto, skirto pabėgèliams ị Lenkiją, Kalkūnèje viršininkas, ir konsulo pavaduotojas pabėgèlių reikalams, taip pat posto „Dykare“ Daugpilyje, čia perèmè reikalus iš Formakovo; Kalkūnuose, Rezeknejje, perèmé reikalus iš buvusio Rusijos pulkininko Danilovo. Jis rinko informaciją apie Raudonają Armiją iš pabėgèlių, išvykstančių iš Rusijos, ir buvo atsakingas už Lenkijos agentų permetimą i Lietuvą Turmanto rajone ir ị Rusiją (iš viso $1921 \mathrm{~m}$. balandị per Kalkūnus i Lenkiją grịžo 598, gegužę - 633, liepą - 1646, rugpjūtị - 795 asmenys). Be to, jis dar turejo sekti veiksmus, kurių imdavosi Latvijos postas Daugpilyje, vadovaujamas leitenanto J. Sausais ${ }^{15}$.

$1921 \mathrm{~m}$. balandị Lenkijos karinio atašè padejjejjui leitenantui A. Klotzui, prižiūrejjusiam ịstaigą, ịsteigtą Lenkijos delegacijos taikos de-

${ }^{15}$ AAN, Attachaty, A-II, 67/2, k. 243, 259, 299, 301, 370, 543; 67/1, k. 3, 11-14, 29, 85, 90; Poczatkowo planowano utworzenie rowniez posterunku „Libawa“ (Liepāja, kierownik - podchorazy Jankowski, wywiad morski, wywiad przeciwko Litwy, miejscowych organizacji komunistycznych, ruch do Gdanska i aktywnosci niemieckiej), jednak z tego zrezygnowano z powodow finansowych. 
rybose sudėtyje po jos išvykimo, Latvijos štabo žvalgybos skyrius pristatė 23 metų agentę Kazimirą Bralę - latvę, gimusią Sakstgalio valsčiuje (Latgala). 1919 m. ji buvo Latvijos agentè, tačiau ,susikompromitavo" ir tapo sovietų agente. 1920 m. rugsẻjo mèn. ji buvo išsiųsta i Lenkijos kariuomenès užnugarị, ten areštuota ir tapo dviguba agente, vẻliau grịžo ị Sovietų Rusiją, kur vẻl buvo areštuota. Jai pavyko pabègti ir grịžti į Latviją, o šalies valdžia ją perdavẻ lenkams. Leitenantas A. Klotzas suvokè, kad ši agentè gali būti labai naudinga Lenkijos žvalgybai, ir išsiunte ją ị Varšuvą. Paskui 1921 m. liepos pab. Latvija perdave atašè tris sulaikytus agentus, B. Savinkovo pasiųstus iš Varšuvos ị Pskovo rajoną (leitenantą F. Bieliakovą, jaunesnijị leitenantą S. Korsakovą ir vachmistrą Čistoblinikovą (Czistoblinnikow), kurie pabėgo į Latviją ${ }^{16}$.

1923 m. pradžioje Lenkijos karinis atašè Latvijoje B. Jarocinskis savo ataskaitoje apie karinius abiejų valstybių santykius pabrèžè, kad nuo 1921 m. rugpjūčio iki 1922 m. gruodžio pasiektas (galbūt sureguliuotas - E. J.) pasikeitimas žvalgybos medžiaga apie Sovietų Rusiją. Minimu laikotarpiu Rusijoje veikė 2 Lenkijos agentai, su kuriais ryšys buvo palaikomas per Latvijos štabą ir du bendrus abiejų štabų agentus $^{17}$. Bendradarbiavimo pobūdis trečiajame dešimtmetyje gerai atsiskleidžia ir 1925 m. gegužès $1 \mathrm{~d}$. atašè biuro ataskaitoje, parengtoje Atstovybès (žvalgybos) viršininkui. Joje kalbama apie Latvijos žvalgybos agentūrinę ịstaigą Latgaloje, kuri renka informaciją apie îvykius Vitebsko, Polocko ir Bobruisko apylinkèse (agentai broliai Bulavai, Mačynskis, Steineris ir kiti). 1925 m. kovą Mačynskis pateikẻ savo darbo rezultatus ir Breslaujos apskrities politinei policijai, už tai gavo iš jos 300 zlotų. Paskui Mačynskis Lenkijos atstovybei pasisiūlè dirbti nuola-

\footnotetext{
${ }^{16}$ AAN, Attachaty, A-II, 67/1, k. 29; A. Peplonski zaznacza, ze urodzona w 1897 roku K. Brale (nieprawidlowo pisze, ze byla Rosjanka) od stycznia do lutego byla wywiadowczynia 498 pulku piechoty Armii rosyjskiej, pozniej, podczas wojny polsko-radzieckiej wykonala zadania specjalne w oddzialach specjalnych, w 1920 roku pracowala w kontrwywiadzie 15 i 3 armii radzieckiej. - Peplonski A. Wywiad w wojnie Polsko-Bolszewickiej 1919-1920. -Warszawa, 1999, p. 284-285.

${ }^{17}$ AAN, Attachaty, A-II/69, k. 286; 67/2, k. 358.
} 
tos, informuodamas, kad kartu lieka susijęs ir su Latvijos žvalgyba. Lenkijos atašè biuras Rygoje pareiškè, kad tokio kontakto nelaiko tinkamu, nes latviai žino apie ji ir gali palaikyti tai bandymu atimti iš jų agentus. Patys latviai „lojaliai“ informuodavo Lenkijos karinị atašè, kuris patarè to nedaryti, nes Latvijos gaunama informacija „yra mūsų kontroliuojama“, ir siūlè nemokèti Mačynskiui už informaciją, nes pats atašè gaudavo tą pačią informaciją iš Latvijos štabo „dykai“. 1922 m. rudeni B. Jarocinskiui Latvijos valdžia suteikè teisę gauti Latvijos užsienio pasus (Lenkijos agentams) ${ }^{18}$.

Baltijos valstybių (taip pat ir Lenkijos) žvalgybų bendradarbiavimo dẻka ịvyko jų atstovųderybos Rygoje 1925 m. kovo 30 d. - balandžio 3 d. (tariamai - nusiginklavimo reikalų ekspertų susitikimas). Aptarta žvalgybos įstaigų organizacija SSSR, radijo žvalgybos koordinavimas, naudojimasis kariniais atstovais ryšiams su rezidentais palaikyti, bendras kontržvalgybos darbas, sureguliuotos informacijos mainų taisyklès, SSSR teritorija (250-300 km i gilumą) paskirstyta ị kiekvienos žvalgybos veikimo ruožus. Nustatyta, kad kiti susitikimai bus organizuojami kas pusmeti (kitas iš eilès susitikimas turẻjo įvykti 1925 m. rudeni), tačiau tai nebuvo igyvendinta dẻl ịvairių priežasčių ${ }^{19}$.

Antroje trečiojo dešimtmečio pusèje, be atsitiktinių žvalgybos karininkų tarpusavio vizitų, reguliariai (kartą per metus, rudenị) dar buvo rengiamos Suomijos, Estijos ir Latvijos kariuomenès štabų žvalgybos skyrių viršininkų konferencijos, kuriose dalyvaudavo ir tų valstybių štabų vadai. Pavyzdžiui, 1927 m. tokia konferencija įvyko Taline, 1928 m. - Helsinkyje, 1929 m. rugsejji - Rygoje. Kaskart būdavo randama dingstis vizitui - pavyzdžiui, $1929 \mathrm{~m}$. tai tariamai buvo iškilmingas paminklo per Pirmaji pasaulinị karą Latvijoje žuvusiems Suomijos šauliams, kovojusiems kariuomenès gretose, atidengimas ${ }^{20}$. Minimu laikotarpiu pažymimas tokio pobūdžio santykių su Lenkija susilpnẻjimas, - tai savo ataskaitose pabrèžè atašè S. Kara (ypač tai, kad lenkai nebu-

18 Tamze, A-II/68, k. 631; CAW, Kolekcja Akt Rosyjskich, t. 1775.

${ }^{19}$ Peplonski A. Wywiad polski na ZSRR. - P. 178-179.

${ }^{20}$ AAN, Attachaty, A-II/75, k. 352. 
vo informuojami apie tokius susitikimus). Tačiau tai buvo paskutinis kelių šalių susitikimas. Tuo pačiu metu Latvijos štabo Operacinio skyriaus žvalgybos sektoriaus vadovas A. Vinteris (Vinters) keletą kartų buvo deleguotas i Varšuvą deryboms su Lenkijos karinès žvalgybos vadovybe (1927 m. liepą ir $1929 \mathrm{~m}$. sausi $)^{21}$. O $1928 \mathrm{~m}$. gegužę paeiliui Rygoje, Taline ir Helsinkyje viešèjo žvalgybos II skyriaus viršininkas A. Studenckis ir sektoriaus „Wschod“ sektoriaus vadovas M. Talikovskis. Pagal Lenkijos pusès ịvertinimą, A. Vinteris derybose Rygoje išlaikè santūrumą ir netgi ịtarumą, neatskleisdamas savo žvalgybos organizacijos SSSR ypatumų, tačiau buvo aptarta situacija Polocko, Vitebsko, Smolensko, Velikije Lukų ir Maskvos srityje. Konstatuota, kad abiejų žvalgybų bendradarbiavimas vyks keičiantis informacija apie SSSR (latvius domino sintetinis Lenkijos žvalgybos informacijos apie situacija Baltarusijos, Ukrainos ir Maskvos karinės apygardoje apdorojimas), ir, kas visų svarbiausia, apibrèžtas bendradarbiavimas grynai žvalgybinėje veikloje: Lenkijos II biuras finansuos nustatytas operacijas, kurios viršija finansines Latvijos žvalgybos galimybes, dèl to lenkai išsiderẻjo, kad jiems būtų atskleisti Latvijos informaciniai šaltiniai ir asmenys, susiję su tomis operacijomis. Tada sektoriaus „Wschod“ karininkas, vadovaujantis žvalgybai iš Latvijos teritorijos, atskleis savo agentūrą ir jos gautą informaciją latviams. Paskui latviai sukurs palankias sąlygas permesti Lenkijos agentams ị SSSR ir palengvinti lenkų kontaktą su Latvijos politine policija. A. Vinteris taip pat išreiškè sutikimą, kad atašè biure dirbtų antras Lenkijos žvalgybos karininkas kaip užsikonspiravęs pareigūnas. Po derybų jau Lenkijos žvalgybos II skyriaus karininkai 1925 m. gegužę pateikẻ slaptą užduotị îstaigai „Dors“, taip pat pabuvojo Daugpilyje, kur išsiaiškino darbo prieš sovietų konsulatą galimybes ir užmezge santykius su Latvijos politine policija ${ }^{22}$.

1930 m. pab. buvo numatytas Latvijos štabo Informacinio skyriaus vadovo G. Kikulio vizitas i Varšuvą. Latvijos pasiuntinys Varšuvoje O. Grosvaldas savo korespondencijoje iš centrinès valdybos Rygoje išreiš-

${ }^{21}$ LVVA, f. 5601, ap. 1, b. 7046, 1. 6-7.

${ }^{22}$ Peplonski A. Wywiad polski na ZSRR. - P. 182-184. 
kè nerimą dèl G. Kikulio ligos, kuri Lenkijos pusei buvo pateikiama tik kaip pretekstas ${ }^{23}$. Tačiau tai buvo tiesa ir $1931 \mathrm{~m}$. sausị G. Kikulis viešèjo Varšuvoje, vesdamas eilines derybas su lenkų žvalgybininkais. Jis buvo siunčiamas ị Varšuvą ir $1933 \mathrm{~m}$. kovą bei dar keletą kartų vẻliau ${ }^{24}$. Tie vizitai buvo organizuojami taip pat su kokia nors dingstimi. Pavyzdžiui, 1933 metų lapkritị i Latvijos nepriklausomybés šventę Rygoje „važiuodamas pro šalị“ iš Helsinkio ị Taliną atvyko Lenkijos II skyriaus viršininkas T. Pelčynskis (Pelczynski), paskui 1933 m. lapkriti atvyko kaip „specialus Gynybos ministerijos atstovas“ dèl „,atašè A. Liebicho ligos“" (net aplanke Rygoje stovintị Latvijos 5-aji péstininkų pulką, tai irgi reikia laikyti reikalavimų dèl dingsties laikymusi $)^{25}$.

Lenkijos konsulate Daugpilyje nuo trečiojo dešimtmečio vidurio iki $1931 \mathrm{~m}$. techniniu darbuotoju dirbo leitenantas S. Kalinovskis, kuris faktiškai stebejo Lenkijos žvalgybos veiklą prieš SSSR ir Lietuvą. Tai buvo daroma su Latvijos štabo sutikimu. İdomu tai, kad jis bendradarbiavo ne tik su Latvijos karine žvalgyba, bet ir politine policija. Pavyzdžiui, 1927 m. spalị kartu su S. Kalinovskiu ì centrinę žvalgybos valdybą (Atstovybę) Vilniuje atvyko Daugpilio rajono policijos viršininkas R. Merginis. Informavęs lenkus apie tai, kad, perbėgus i Latviją sovietų agentui, buvo atskleista dvylika sovietinès žvalgybos tinklo „pasienio būrių“ ir areštuota apie 30 jos agentų (tarp jų - keli Latvijos pasienio sargybiniai). R. Merginis pabrèžè galimybę susieti tą tinklą ir su Lenkija bei išreiške norą užmegzti ryšị su Lenkijos žvalgyba bendrai kovai su tinklu. Ir nors R. Merginis nepateikè konkrečiu siūlymų dèl tolesnio bendradarbiavimo, jau pats tokio susitikimo faktas yra iškalbingas ${ }^{26}$. İdomu tai, kad praejjus ménesiu po to apsilankymo Vilniuje, 1927 m. lapkričio 26 d., S. Kalinovskis net pranešè R. Merginiui apie tai, kad gavo užduotị atskleisti, ar prie Latvijos ir Lietuvos sienos

\footnotetext{
${ }^{23}$ LVVA, f. 2575, ap. 15, b. 15, 1. 73-74.

${ }^{24}$ LVVA, f. f. 5601, ap. 1, b. 3434, 1. 4-6.

${ }^{25}$ Nasz Glos. - 193211 25; 19331119.

${ }^{26}$ AAN, Attachaty, A-II/73, k. 61.
} 
lietuvių pusėje nepastebèta jokio judèjimo, susijusio su gandais apie slaptą mobilizaciją Lietuvoje ${ }^{27}$. S. Kalinovskio apsilankymas Latvijoje, pana iai kaip ir abiejų valstybių kariniai santykiai, buvo priklausomi nuo politinių Latvijos ir Lenkijos santykių. $1931 \mathrm{~m}$. dèl tariamai nepalankaus Latvijos valdžios požiūrio ị lenkų mažumą keliems mėnesiams iš Latvijos išvyko Lenkijos pasiuntinys M. Arciševskis (Arciszevski), o santykiai buvo labai komplikuoti (pasiuntinys grị̌o ị Rygą tik 1932 metu pavasarị). Tuo savo interesams stangèsi pasinaudoti Lietuvos Vyriausybė. $1931 \mathrm{~m}$. spali Lietuvos dienraštis paskelbė informaciją apie S. Kalinovskio vadovaujamą slaptosios policijos agentų akciją prieš Lietuvą Daugpilyje (prisiminta apie jo korespondenciją su Atstovybe Vilniuje, kurią lietuviai perémé). Latvijos Užsienio reikalų ministerija atsake, kad diplomatinių atstovų sąrašuose jokio S. Kalinovskio nėra ${ }^{28}$. Spalio 23 d. Latvijos pasiuntinys Kaune R. Liepinis (Liepiņš) Lietuvos valdžiai reikalaujant prašè informacijos apie Kalinovskị, kurią iš URM gavo. Spalio $30 \mathrm{~d}$. atsakyme pažymima, kad S. Kalinovskio veikla yra žinoma, tačiau dèl susikomplikavusių Latvijos ir Lenkijos santykių šiuo metu URM nemano esant „tinkamu momentu“ išsiųsti jị iš Latvijos (be to, pabrèžti Lietuvos interesai: šalis Daugpilyje taip pat turi savo agentų, „kuriems jų lenkai kolegos yra labai „nepageidaujami“ $)^{29}$. Tačiau lapkričio 24 d. S. Kalinovskis - Vilniaus atstovybès agentas „0-II“ (II skyriaus) gavo Vidaus reikalų ministro įsakymą išvykti iš Latvijos iki gruodžio $12 \mathrm{~d} .{ }^{30}$.

Ketvirtajame dešimtmetyje (iki 1936 m. liepos) konsulato Rygoje sekretoriumi dirbo jaunesnysis leitenantas K. Rokickis, kuris kartu buvo Lenkijos II skyriaus sektoriaus „Wschod“ rezidentas, veikiantis prie SSSR ir Lietuvos (bendradarbiavęs su II skyriumi kaip informatorius nuo 1931 m., kai dirbo generaliniame konsulate Minske). İdomu tai, kad tuo kartu apie ji nebuvo informuoti ne tiktai latviai, bet ir pasiunti-

\footnotetext{
${ }^{27}$ LVVA, f. 3235, ap. 1/22, b. 462, 1. 34.

${ }^{28}$ Dziennik Wilenski.- 1931.

${ }^{29}$ LVVA, 2575. f. 2575, ap. 15, b. 142, 1. 303.

${ }^{30}$ AAN, Attachaty, A-II/77, k. 27.
} 
nys Latvijoje F. Charvatas. Kai jis apie tai sužinojo 1935 m. pabaigoje, kilo skandalas (tiesa, jis įvyko tik Lenkijos vidaus institucijų mastu). F. Charvatas buvo nepatenkintas, kad rezidentas atsirado be jo žinios, o II skyriaus viršininkas T. Pelčynskis 1936 m. kovą rašè, kad pasiuntinys - „kuoktelejjęs senas isterikas su perdètomis ambicijomis ir visiškai nenuspejamais temperamento sprogimais“. Kaip tik dèl to K. Rokisckis turejjo išvažiuoti iš Rygos ${ }^{31}$.

Didžiausią efektą davė abiejų žvalgybų bendradarbiavimas radijo pasiklausymo srityje (jau trečiojo dešimtmečio pradžioje būta latvių bandymų užmegzti šio pobūdžiokontaktą). Trečiojo dešimtmečio pradžioje per Lenkijos karinị atašė Latvijos pusei pavyko gauti Lenkijoje pagamintos radijo pasiklausymo stoties instrukciją, tačiau pats pirkimas dẻl Lenkijos pusès neryžtingumo neịvyko (1922 m. balandị atašė B. Jarocinskis perspejo II skyrių: „Tačiau pačios stoties atsiuntimas sukels mums nepageidaujamų klausimų ir su tuo susijusių abejonių“32). Reguliarūs apsikeitimai radijo žvalgybos perimta informacija buvo pradėti trečiojo dešimtmečio pabaigoje. Keičiamasi buvo per Lenkijos karini atašẻ Rygoje (nuo 1931 m. gegužès - 2 karus per mėnesị). 1931 m. liepą Latvijos pusė ị savo klausimą apie vietą, kurioje perimama (pasiklausoma) informacija, gavo atsakymą, kad tai radiotelegrafo plutonas Vilniuje (buvo nurodyti ir tikslūs geografiniai duomenys) ${ }^{33}$.

1933 m. sausi su vizitu ị Rygą atvyko majoras Ušackis (Uszacki) iš Generalinio štabo II skyriaus, kad užmegztų ryši su Latvijos štabu dẻl radijo žvalgybos reikalų SSSR. Jis turejjo konkretų pasiūlymą priimti Latvijos specialistą 2 savaičių mokymams radijo žvalgybos centrinėje valdyboje Varšuvoje - ši pasiūlymą mielai prièmè pulkininkas G. Kikulis. Paskui Ušackis pripažino, kad latviai „patys parodo viską“. Kartu su Ušackiu, grịžtančiu i Lydą (ị ten esančią radijo žvalgybos stotị), atvyko ir kapitonas P. Kažmersas (Kažmers), o ị 2 savaičių mokymo kursus Varšuvoje išvažiavo pavėliavininkis K. Porietis $^{34}$. Varšuvoje K. Porietis

\footnotetext{
${ }^{31}$ AAN, Attachaty, A-II, 86/2, k. 523, 525, 540; Nasze Zycie. - 1936.

${ }^{32}$ AAN, Attachaty, A-H/68, k. 186.

${ }^{33}$ AAN, Attachaty, A-H/77, k. 14, 16, 145.

${ }^{34}$ AAN, Sztab Glovny, t. 616/151, k. 4; LVVA, f. 2575, ap. 15, b. 115, 1. 51.
} 
išèjo specialų mokymo kursą, kurio metu buvo supažindintas su Lenkijos radijo žvalgybos darbo metodais, dešifravimo metodais ir, jo paties prisipažinimu, gavo svarbios informacijos, būtinos tolesniam darbui (nors „lenkai man akivaizdžiai neparodė naujausių savo laimèjimų“). Minètame susitikime Rygoje nustatyta pasiskirstyti žvalgybos sritis ir tęsti jau prieš tai pradètą apsikeitimą perimta radijo žvalgybos informacija. Tokie apsikeitimai vyko ${ }^{35}$. Kelis kartus Lenkijos pusė apkaltino pavèluotu latviu gautos informacijos perdavimu Lenkijos ataše Rygoje, tačiau tie vẻlavimai nebuvo reikšmingi, pavyzdžiui, nepateikta medžiaga nuo 1935 m. birželio iki rugpjūčio. 1935 m. rugsejị atašè A. Liebechas derybose su G. Kikuliu perdave jam žinią, kad Lenkijos pusė sutinka išplėsti minètą informaciją, ir pabrèžè, kad Lenkijos specialistai aukštai vertina latvių radijo pasiklausymo organizavimą ir papulkininkio P. Kažmeio - Latvijos kariuomenès štabo Informacinio skyriaus sektoriaus vadovo - darbą. Savo ruožtu G. Kikulis pažadejo duoti įsakymą pagreitinti „savo medžiagos ekspediciją “36.

1936 m. vasarị i Rygą atvyko LK Vyriausiojo štabo II skyriaus viršninkas papulkininkis J. Englichtas ir to paties skyriaus karininkas majoras S. Šcekovskis, kuris vedè 2 dienų derybas su Latvijos štabo Informacinio skyriaus vadovybe. Lenkai buvo labai patenkinti tų derybų rezultatais, nes ,jos vyko labai širdingoje atmosferoje“, latviai atskleide kur kas daugiau informacijos negu kada nors anksčiau, net neslëpdami savo informacijos šaltinių. Pabaigoje Latvijos pusẻ pateike siūlymą organizuoti panašius susitikimus kas pusmetị, kad galima būtų suderinti abiejų skyrių veiklą ${ }^{37} .1936 \mathrm{~m}$. birželị ir gruodị (atitinkamai Varšuvoje ir Rygoje) bei 1937 m. gegužę (Varšuvoje) iš tikrųjų ivyko eiliniai susitikimai, kurių rezultatai abiejų šalių taip pat buvo aukštai ịvertinti. Latvijos delegacijai paprastai vadovaudavo G. Kikulis, o du paskutinius kartus delegacijoje buvo sektoriaus vadovas papulkininkis F. Celminis

\footnotetext{
${ }^{35}$ Porietis K. Latvijas bruṇoto spēku radio izlūkošanas dienests // Strēlnieks. - 1970, Nr. 20/23, p. 45-46.

${ }^{36}$ AAN, Sztab Glowny, t. 616/178, k. 129, 147.

${ }^{37}$ AAN, Ministerstwo Spraw Zagranicznych, t. 6201, k. 34.
} 


\section{$(\text { Celminšs })^{38}$.}

Labai komplikuoti Baltijos šalių ir Lenkijos santykiai atsispindejo taip pat Latvijos žvalgybos požiūryje ị Latvijos teritorijoje konfrontuojančias Lenkijos ir Lietuvos žvalgybas. 1930 m. rugpjūtị Latvijos kariuomenès štabo Operacinio skyriaus Informacinio sektoriaus $(1934 \mathrm{~m}$. buvo įkurtas atskiras Informacijos skyrius) vadovas pulkininkas G. Kikulis privačiame pokalbyje su Lenkijos ataše S. Kara pažymėjo, kad Lenkijos žvalgybinè veikla prieš Lietuvą Latvijoje nèra kritikuotina ir netgi yra pasirengęs lenkams padèti, informuodamas apie Latvijos žvalgybos atskleistą antilenkišką „lietuvišką veiklą“ Rygoje: lietuvių agentas, apkvaitęs nuo alkoholio, pasisakè informatoriui, kad žino Lenkijos žvalgybos struktūrą Latvijoje, paminėdamas agentą S. Kalinovskị Daugpilyje ir kelias tarsi eilinių agentų Rygoje pravardes. Atašė padèkojo, žadejjo perspèti žvalgybininkus didžiausiuose Rygos viešbučiuose ir paprašè taip pat ir toliau išlaikyti palankų požiūrị i savo žvalgybą ${ }^{39} .1931$ m. balandị S. Kara vèl gavo „slaptos“ informacijos iš Latvijos štabo, kad atskleista lietuvių žvalgybinė veikla prieš Lenkiją Daugpilyje, kuriai vadovauja vietinis Lietuvos konsulatas, o iggyvendina agentai pašte, kontroliuodami korespondenciją. Kara gavo „lojalų“ perspejjimą nesiųsti svarbios informacijos ị Daugpilị ir užtikrinimą, kad latviai nèra nusistatę prieš lenkų žvalgybinę veiklą toje vietoje. Pagaliau pats S. Kara jau žinojo apie Lietuvos atašè ir 2 agentų vykdomą žvalgybinę veiklą Rygoje, tačiau laikẻ grupę Daugpilyje ir jos atliekamą S. Kalinovskio „sekimą“ nepavojingu. İdomu tai, kad žvalgybos reikalai buvo nagrinèjami privačiame S. Karos pokalbyje su Lietuvos kariniu atašè Rygoje B. Giedraičiu. 1929 m. spali pastarasis, apsvaigęs nuo alkoholio, pasakẻ Lenkijos atašè: „Nusiramink ir nesiųsk daugiau moterų i Kauną!“. Iš to S. Kara padare išvadą, kad agentè, dirbanti Rygoje Lenkijos žvalgybai, iškonspiruota (galimas daiktas, yra dviguba agentè) ${ }^{40}$.

${ }^{38}$ LVVA, f. 5601, ap. 1, b. 3434, 1. 5, b. 1134, 1. 6; AAN, Sztab Glovvny, t. 616/234, k. 140; t. 616/261, k. 409.

${ }^{39}$ AAN, Attachaty, A-II/76, k. 226.

${ }^{40}$ AAN, Attachaty, A-II/77, k.. 4 
Apibendrinant reikia padaryti išvadą, kad Latvijos ir Lenkijos žvalgybos tarnybų kontaktai 1919-1939 m. buvo ne tokie glaudūs, kaip galëjo būti, jeigu abiejų valstybių, pagaliau ir visų Baltijos šaliu politiniai santykiai būtų buvę geresni. Latvijos santykiai su Lenkija apskritai buvo geri, nors buvo ir labai komplikuotų laikotarpių (pavyzdžiui, 1931 m. rudenį), tačiau nebuvo abipusio įtarinèjimo. Kariniai santykiai buvo priklausomi nuo politinių, nors buvo juntama gerejimo tendencija (lygyje, priklausančiame išskirtinai nuo atsakingų kariškių). Paskui abiejų valstybių žvalgybų bendradarbiavimas buvo vienas naudingiausių tų karinių santykių aspektas.

Iteikta $2004 \mathrm{~m}$. vasario $26 \mathrm{~d}$. 


\title{
Résumé
}

\section{Collaboration des services des renseignements lettons et polonais en 1919-1939}

\author{
Dr. Ēriks Jēkabsons, \\ Université de Lettonie
}

La collaboration entre les services des renseignements polonais et lettons s'est établie en été 1919. Cependant, pendant les années 1919-1939 les contacts entre les services des renseignements polonais et lettons étaient moins étroits qu'ils auraient pu l'źtre si les rapports politiques entre ces deux états et enfin entre tous les Etats Baltes étaient meilleurs. La Lettonie et Pologne, en général, étaient en bons termes, bien qu'il fūt des périodes compliquées (par exemple l'automne 1931), cependant tout soupēon réciproque füt exclu de ces rapports. Les rapports militaires dépendaient des rapports politiques bien qu'on remarquât la tendance vers amélioration, et notamment au niveau qui dépendait exceptionnellement des officiers responsables. Ensuite la collaboration entre les services des renseignements des deux états constituait l'un des aspects les plus utiles de ces rapports militaires. Les services des deux états échangeaient de l'information relative ą l'Union Soviétique, Lituanie, en partie l'Allemagne. Les résultats les plus effectifs était de la collaboration des services des renseignements dans le domaine des écoutes de radio. 